Table 1.

\begin{tabular}{|c|c|c|c|}
\hline $\mathrm{NCM}$ & $\begin{array}{l}\mathrm{SSc} P H \\
(\mathrm{n}=40)\end{array}$ & $\begin{array}{c}\text { SSc noPH } \\
(n=38,2 \text { missing })\end{array}$ & $P$ value \\
\hline Mean capillary density/mm $( \pm S D)$ & $5.0( \pm 1.4)$ & $5.4( \pm 1.6)$ & 0.39 \\
\hline $\begin{array}{l}\text { Mean number of fingers with } \\
\text { density }<3( \pm S D)\end{array}$ & $2.3( \pm 1.9)$ & $1.7( \pm 2.1)$ & 0.20 \\
\hline $\begin{array}{l}\text { Mean abnormally shaped capillar- } \\
\text { ies } / \mathrm{mm}( \pm \mathrm{SD})\end{array}$ & $1.2( \pm 0.46)$ & $0.99( \pm 0.53)$ & 0.07 \\
\hline NCM pattern $(n)$ & & & 0.103 \\
\hline Normal/aspecific & 1 & 3 & \\
\hline early & 0 & 3 & \\
\hline active & 4 & 7 & \\
\hline late & 34 & 25 & \\
\hline Not interpretable & 1 & 2 & \\
\hline Biomarkers* & $\begin{array}{c}\text { SSc } \mathrm{PH} \\
(\mathrm{n}=33,7 \text { missing) } \\
\text { IQR) }\end{array}$ & $\begin{array}{c}\text { SSc noPH } \\
(n=40) \\
\text { (median, IQR) }\end{array}$ & $P$ value \\
\hline IL6 pg/ml & $4.8(1.7-8.2)$ & $2.5(1.3-5.6)$ & 0.047 \\
\hline PDGF-AB-BB pg/ml & 29535 (24777-33458) & 32221 (29409-37549) & 0.0034 \\
\hline sTRAIL pg/ml & $36.6(20,4-50,6)$ & $60.8(40.7-82.4)$ & $<0.0001$ \\
\hline sVCAM1 ng/ml & $311(254-374)$, & $265(228-323)$ & 0.0236 \\
\hline Endostatin ng/ml & $53.8(41.9-72.6)$ & $39(28.6-46)$ & $<0.0001$ \\
\hline sVEGFR2 pg/ml & 10388 (7276- 13323) & $13736(10282-16554)$ & 0.0006 \\
\hline $\mathrm{CXCL} 4 \mathrm{ng} / \mathrm{ml}$ & $3347(2546-4708)$ & $5309(4089-6322)$ & $<0.0001$ \\
\hline VEGF-A pg/ml & $672(248-955)$ & $346(175-703)$ & 0.0424 \\
\hline VEGF-D pg/ml & $671(421-1012)$ & $515(262-734)$ & 0.0296 \\
\hline
\end{tabular}

* only significant values with a $p<0.05$ are shown

Disclosure of Interests: Jacqueline Lemmers: None declared, C.H.M. van den Ende: None declared, R. Smeets: None declared, Brigit Kersten: None declared, Arjan van Caam: None declared, Sander van Leuven: None declared, Jolanda van Haren-Willems: None declared, Arie van Dijk Speakers bureau: Actelion(Janssen), Consultant of: Actelion(Janssen), Grant/research support from: Unrestricted educational Grant for PhD student from Actelion (Janssen), Madelon Vonk Speakers bureau: Actelion(Janssen), Boehringer Ingelheim, Roche, Consultant of: Advisory Board from Actelion(Janssen) and Boehringer Ingelheim, Grant/research support from: Unrestricted Educational Grant and research support from Actelion(Janssen), research support from Ferrer DOI: 10.1136/annrheumdis-2021-eular.2722

\section{AB0442 $\quad$ CLINICAL FEATURES OF POLYMYOSITIS AND DERMATOMYOSITIS PATIENTS WITH SEVERE DYSPHAGIA}

Y. Hayashi ${ }^{1}$, K. Izumi ${ }^{1}$, S. Hama ${ }^{1}$, M. Higashida-Konishi ${ }^{1}$, M. Ushikubo ${ }^{1}$ H. Oshima ${ }^{1}$, Y. Okano ${ }^{1} .{ }^{1}$ National Hospital Organization Tokyo Medical Center, Rheumatology, Tokyo, Japan

Background: Polymyositis (PM) and dermatomyositis (DM) are autoimmune inflammatory diseases characterized by proximal myositis. Dysphagia has been reported to develop in 35 to $62 \%$ of PM/DM patients and known as poor prognosis factor.

Objectives: The purpose of this study is to determine the clinical characteristics of PM/DM patients who present with deglutition disorder.

Methods: Consecutive patients with PM/DM who visited National Hospital Organization Tokyo Medical Center between April 2010 and January 2021 are included in this study. We compared clinical features between the patients with and without dysphagia. The diagnosis of dysphagia was based on videofluorography swallow study, and dysphagia requiring gastrostomy was defined as severe dysphagia. The clinical characteristics compared in this study were following: age of onset, levels of serum creatine kinase (CK) and lactate dehydrogenase(LDH), sense of dysphagia, manual muscle test (MMT) score, and complication of malignancy or interstitial pneumonia.

Results: A total of 73 patients with PM/DM were identified. Among them, 12 patients were diagnosed with dysphagia, and 5 patients developed severe dysphagia. Patients with dysphagia had the following characteristics compared to patients without dysphagia: higher levels of serum LDH $(833.7 \pm 500.1 \mathrm{U} / \mathrm{L}$ vs $471.9 \pm 321.0 \mathrm{U} / \mathrm{L}, \mathrm{p}=0.0088)$, higher levels of serum CK at initial examination $(6070.3 \pm 7184.8 \mathrm{IU} / \mathrm{L}$ vs $1534.7 \pm 2978.8 \mathrm{IU} / \mathrm{L}, \mathrm{p}=0.0086)$ and more frequent sense of dysphagia $(90.9 \%$ vs $10.6 \%, p<0.0001)$, lower MMT score(3.18 \pm 1.07 vs $4.31 \pm 0.75, p=0.0017)$. In addition to those, patients with severe dysphagia presented older age of onset (mean age $69.4 \pm 12.0$ vs $51.7 \pm 14.8, p=0.014$ ), more frequent complication of malignancy $(80.0 \%$ vs $14.8 \%, p=0.0048)$ and less frequent complication of interstitial pneumonia ( $0.0 \%$ vs $55.5 \%, p=0.023)$. Conclusion: These results indicate that dysphagia develops frequently in $\mathrm{PM} /$ DM patients with higher levels of serum LDH or CK, sense of dysphagia and low MMT score. Among them, patients with elderly onset or malignancy are at risk for sever dysphagia, and should be treated carefully.

Disclosure of Interests: None declared.

DOI: 10.1136/annrheumdis-2021-eular.2757

\section{$\mathrm{AB} 0443$ \\ BIOMARKER SUCH AS IL-17, IL-21 AND TIMP-1, IS USEFUL FOR PREDICTING THE PATHOPHYSIOLOGY OF CONNECTIVE TISSUE DISEASE-ASSOCIATED PULMONARY HYPERTENSION}

S. Nakashima ${ }^{1}$, T. Kameda ${ }^{1}$, H. Shimada ${ }^{1}$, M. Mahmoud Fahmy Mansour ${ }^{1}$, R. Wakiya ${ }^{1}$, M. Kato ${ }^{1}$, Y. Ushio ${ }^{1}$, K. Sugihara ${ }^{1}$, H. Dobashi ${ }^{1}{ }^{1}$ Kagawa University, Division of hematology, Rheumatology and Respiratory Medicine, Department of Internal medicine, Kagawa, Japan

Background: Connective tissue disease-associated pulmonary hypertension (CTD-PH) is constructed by a variety of pathologies, including cardiac, pulmonary, and vascular involvement, as well as immune abnormalities. Because of its various constructs, it is difficult for many respiratory physicians, cardiologists, and rheumatologists to determine a treatment strategy for CTD-PH. In addition, CTD-PH has different pathologies from $\mathrm{PAH}$, and there are cases in which immunosuppressive therapy is effective. These suggests that the two PAHs may have different pathogenesis, including inflammation in the pulmonary artery. However, there are not enough biomarkers to distinguish pathologies. On the other hand, it has been reported that various cytokines such as TIMP-1, Interleukin (IL)-6, IL-17, and IL-21 are involved in the pathogenesis of CTD-PH or vasculitis. $(1,2)$ However, the relationship between these cytokine expression and the pathogenesis or treatment of CTD-PH has not been fully clarified.

Objectives: To clarify the relationship between cytokine profile and clinical features, change in cytokines and hemodynamics by treatment, association with the effectiveness of immunosuppressive therapy.

Methods: Patients suspected PH was included. At the time of cardiac catheterization( $\mathrm{RHC})$, sera in pulmonary pre and post-capillary were collected and TIMP-1, MCP-1, IL-17 and IL-21, IL-12p70 and IL-6 were analyzed by ELISA(ABCAM UK, Ella simple plex USA). The following clinical data were collected: age, gender, underlying disease, complication of interstitial lung disease, treatment (immunosuppressant and pulmonary vasodilator), hemodynamics. Furthermore, we investigated the relationship between cytokines and clinical data.

Results: 15 cases of CTD-PH, 13 cases of non-CTD-PH, and 6 cases of non-PH were analyzed. (SSc 12 cases, MCTD 7cases, SLE 2 cases, and others 13 cases) 28 cases were diagnosed with $\mathrm{PH}$ by $\mathrm{RHC}$. There was a positive correlation between IL- 6 and mean pulmonary arterial pressure in all $\mathrm{PH}$ case. In addition, MCP-1, IL-6, and TIMP-1 tend to be high in SSc-PH cases. On the other hand in Non-SSc-PH, IL-12p70 and IL-17 were high. In cases who pulmonary vascular hemodynamics improved by treatment, IL-17, IL-21, and TIMP-1 decreased.

Conclusion: Biomarker profiles in pulmonary capillaries may differ depending on the disease. Furthermore, it suggested that IL-17, IL-21 and TIMP-1 may be biomarkers of therapeutic effect.

\section{REFERENCES:}

[1] Hashimoto-Kataoka T. et al. Proc Natl Acad Sci U S A. 2015 May 19;112(20):E2677-86.

[2] Jun Ishizaki et al. Arthritis Res Ther. 2017 Sep 29;19(1):218

Disclosure of Interests: None declared.

DOI: 10.1136/annrheumdis-2021-eular.2765

\section{AB0444 CLINICAL-IMMUNOLOGICAL CHARACTERISTICS OF PATIENTS WITH INFLAMMATORY MYOPATHIES}

A. Khelkovskaia-Sergeeva ${ }^{1}$, O. Desinova ${ }^{1}$, M. Starovoytova ${ }^{1}$, L. P. Ananyeva ${ }^{1}$, M. Cherkasova ${ }^{2}, \mathrm{R}$. Shayakhmetova ${ }^{1}{ }^{1}$ VA Nasonova Research Institute of Rheumatology, Laboratory of Microcirculation and Inflammation, Moscow, Russian Federation; ${ }^{2}$ VA Nasonova Research Institute of Rheumatology, Laboratory of Immunology and Molecular Biology, Moscow, Russian Federation

Background: Inflammatory disorders of the skeletal muscle include polymyositis (PM), dermatomyositis (DM), amyopathic dermatomyositis ADM, (immune mediated) necrotizing myopathy (NM), overlap syndrome with myositis (overlap myositis, OM) and including anti-synthetase syndrome (ASS).

The detection of myositis-specific antibodies, the clinical effect of which remains to be determined, may be of great importance for diagnosis.

Objectives: To study clinical-immunological characteristics of patients with inflammatory myopathies.

Methods: 57 pts were enrolled in this study: 28 (47\%) pts were diagnosed with DM, 14 (23\%) pts - OM, 5(8\%) pts - PM, 5 (8\%) pts-NM, 4 (7\%) pts-ADM, 1 (2\%)- ACC. Duration of disease in average 11,29 (2-48) month. Standard clinical examination and laboratory immunological evaluation including myositis-specific autoantibodies were performed.

Results: There were 3 age groups: $18-39$ years old - 16 (28\%) pts, 40-49 yo $-28(49 \%)$ pts and > 60 yo $-13(33 \%)$ pts. Symptoms of myositis were muscle weakness $57(100 \%)$ pts, dysphagia $29(51 \%)$ pts, arthritis $-12(21 \%)$ pts, Raynaud's phenomenon 21 (37\%) pts, skin lesions- 37 (65\%) pts (Gottron signs- 7 $(12 \%)$ pts, digital ulcers -11 (19) pts, panniculitis $-6(11 \%)$ pts, hand of mechanic $16(28 \%)$ pts). MMT 8 was 55,57 (SD 18,49) $(20-80)$ score. Clinical features of myositis were myocarditis $8(14 \%)$ pts and arrhythmia $9(16 \%)$ pts, interstitial lung 
disease $20(35 \%)$ pts, esophageal involvement $29(51 \%)$ pts of them $5(9 \%)$ pts needed enteral feeding. 2 (4\%) pts had oncopathology. CK was increased in 49 (86\%) pts: < $10 \mathrm{~N}-15$ (26\%) pts, >10 N - 28 (49\%) pts, > $50 \mathrm{~N}-6(11 \%)$. ANA positive - in 39 (70\%) pts. Antibodies identified in 25(44\%) pts: Pm-Scl 7 (12\%) pts, PL-7 1 (2\%), Mi-2 10 (17,5\%), Ku 2 (3,5\%) pts, AMA-M2 2 (2\%)pts, a-SRP 4 (7\%) and SS-A/Ro-52 13 (23\%), SS-A/Ro-60 2 (3\%) pts.

Conclusion: The group of inflammatory myopathies is characterized by clinical and immunological heterogeneity. Finding antibodies specific for myositis can help diagnose the disease.

Disclosure of Interests: None declared.

DOI: 10.1136/annrheumdis-2021-eular.3101

\section{AB0445 $\quad$ FIRST CLINICAL ANALYSIS OF MYOSITIS PATIENTS REGISTERED AT REUMA.PT/MYOSITIS PROTOCOL: DATA FROM A SINGLE-CENTER}

A. T. Melo ${ }^{1,2}$, E. Dourado ${ }^{1,2}$, P. Martins ${ }^{1,2}$, N. Khmelinskii ${ }^{1,2}$, J. E. Fonseca ${ }^{1,2}$ I. Cordeiro ${ }^{1,2}$, R. Campanilho-Marques ${ }^{1,2}$. $^{1}$ Lisbon, Serviço de Reumatologia e Doenças Ósseas Metabólicas, Hospital de Santa Maria, CHULN, Centro Hospitalar Universitário Lisboa Norte, Lisbon, Portugal; ${ }^{2}$ Lisbon, Unidade de Investigação em Reumatologia, Instituto de Medicina Molecular, Faculdade de Medicina, Universidade de Lisboa, Centro Académico de Medicina de Lisboa, Lisbon, Portugal

Background: Idiopathic inflammatory myopathies are a group of rare heterogeneous diseases that require a multidisciplinary and standardized approach.

Table 1. Clinical characteristics and immunological profile of the patients.

\begin{tabular}{|c|c|c|c|c|c|c|}
\hline \multirow[t]{2}{*}{ Diagnosis (n) } & \multicolumn{5}{|c|}{ Clinical features } & \multirow[t]{2}{*}{ Myositis antibodies (n) } \\
\hline & $\begin{array}{l}\text { Skin } \\
\text { disease, } \\
\text { median } \\
{[I Q R] /(n)}\end{array}$ & $\begin{array}{c}\text { MMT-8, } \\
\text { median } \\
\text { [IQR] }\end{array}$ & $\begin{array}{l}\text { Lung } \\
\text { disease } \\
\text { (n) }\end{array}$ & $\begin{array}{l}\text { Others } \\
(n)\end{array}$ & $\begin{array}{l}\text { Malignancy } \\
\text { (n) }\end{array}$ & \\
\hline $\begin{array}{l}\text { Definite DM } \\
\quad(28)\end{array}$ & $\begin{array}{l}\text { DAS Skin } \\
2 \text { [0-2] } \\
\text { Calcinosis } \\
\text { (3) } \\
\text { Mechanic } \\
\text { hands (2) }\end{array}$ & $\begin{array}{c}80 \\
{[75-80]}\end{array}$ & $\begin{array}{c}\text { NSIP } \\
(2) ; \\
\operatorname{COP}(1)\end{array}$ & $\begin{array}{l}\text { Arthritis } \\
\text { (6) }\end{array}$ & $\begin{array}{l}\text { Breast } \\
\text { cancer } \\
(1)\end{array}$ & $\begin{array}{l}\text { anti-Ro52 (6); anti-Mi2b } \\
\text { (5); anti-PmScl100 (4); } \\
\text { anti-MI2a (3); anti-NXP2 } \\
\text { (3); anti-SAE (2); anti- } \\
\text { MDA5 (2); anti-Ku (2); } \\
\text { anti-Tif1g (1) }\end{array}$ \\
\hline $\begin{array}{l}\text { Antisynthetase } \\
\text { syndrome } \\
\text { (21) }\end{array}$ & $\begin{array}{l}\text { DAS Skin } \\
0[0-0] \\
\text { Calcinosis } \\
(1) \\
\text { Mechanic } \\
\text { hands (4) }\end{array}$ & $\begin{array}{c}80 \\
{[80-80]}\end{array}$ & $\begin{array}{l}\text { NSIP } \\
(11) ; \\
\text { UIP (3); } \\
\operatorname{LIP}(1)\end{array}$ & $\begin{array}{l}\text { Arthritis } \\
\text { (15); } \\
\operatorname{RP}(10)\end{array}$ & - & $\begin{array}{c}\text { anti-Jo1 (14); } \\
\text { anti-Ro52 (12); } \\
\text { anti-Mi2b (1); } \\
\text { anti-PL7 (3); } \\
\text { anti-PL12 (1) }\end{array}$ \\
\hline $\begin{array}{l}\text { Probable DM } \\
\text { (19) }\end{array}$ & $\begin{array}{l}\text { DAS Skin } \\
0[0-0]\end{array}$ & $\begin{array}{c}80 \\
{[78-80]}\end{array}$ & COP (1) & $\begin{array}{l}\text { Arthritis } \\
(5) ; \\
\operatorname{RP}(6)\end{array}$ & - & $\begin{array}{c}\text { anti-Mi2a (4); } \\
\text { anti-Mi2b (2); anti-Tif1g (2); } \\
\text { anti-Ku (2); } \\
\text { anti-PmScl75 (2) }\end{array}$ \\
\hline CADM (16) & $\begin{array}{l}\text { DAS Skin } \\
1 \text { [0-2] } \\
\text { Calcinosis } \\
(1) \\
\text { Mechanic } \\
\text { hands (1) }\end{array}$ & $\begin{array}{c}80 \\
{[77-80]}\end{array}$ & $\begin{array}{l}\text { NSIP } \\
(1) ; \\
\text { COP } \\
(1)\end{array}$ & $\begin{array}{l}\text { Arthritis } \\
\text { (5); } \\
\operatorname{RP}(4)\end{array}$ & - & $\begin{array}{c}\text { anti-Mi2b (5); } \\
\text { anti-Ro52 (2); anti-Mi2a (1); } \\
\text { anti-MDA5 (1); anti-EJ (1); } \\
\text { anti-SAE (1); anti-SRP (1); } \\
\text { anti-Ku (1); anti-Tif1g (1) }\end{array}$ \\
\hline MCTD (12) & $\begin{array}{l}\text { DAS Skin } \\
0[0-1]\end{array}$ & $\begin{array}{c}80 \\
{[79-80]}\end{array}$ & $\begin{array}{l}\text { NSIP } \\
(1)\end{array}$ & $\begin{array}{l}\text { Arthritis } \\
\quad(8) ; \\
\operatorname{RP}(10)\end{array}$ & - & $\begin{array}{l}\text { anti-U1 RNP (12); } \\
\text { anti-Ro52 (7) }\end{array}$ \\
\hline PM (7) & $\begin{array}{l}\text { DAS Skin } \\
0[0-0] \\
\text { Calcinosis } \\
(1)\end{array}$ & $\begin{array}{c}80 \\
{[72-80]}\end{array}$ & $\begin{array}{l}\text { NSIP } \\
(1)\end{array}$ & $\begin{array}{l}\text { Arthritis } \\
\text { (1) }\end{array}$ & $\begin{array}{l}\text { Ovarian cancer } \\
\text { (1); non-Hodg- } \\
\text { kin lymphoma } \\
\text { (1) }\end{array}$ & $\begin{array}{c}\text { anti-Ro52 (2); } \\
\text { anti-SRP (1) }\end{array}$ \\
\hline UCTD (5) & $\begin{array}{l}\text { DAS Skin } \\
0[0-2] \\
\text { Calcinosis } \\
\quad(1) \\
\text { Mechanic } \\
\text { hands (1) }\end{array}$ & $\begin{array}{c}80 \\
{[79-80]}\end{array}$ & $\begin{array}{l}\text { NSIP } \\
(2)\end{array}$ & $\begin{array}{l}\text { Arthritis } \\
\quad(1) ; \\
\operatorname{RP}(5)\end{array}$ & - & $\begin{array}{l}\text { anti-ThTo (2); } \\
\text { anti-SRP (1); } \\
\text { anti-PL12 (1) }\end{array}$ \\
\hline $\begin{array}{l}\text { Overlap syn- } \\
\text { dromes (12) }\end{array}$ & $\begin{array}{l}\text { DAS Skin } \\
0 \text { [0-2] } \\
\text { Mechanic } \\
\text { hands (2) }\end{array}$ & $\begin{array}{c}80 \\
{[77-80]}\end{array}$ & $\begin{array}{l}\text { NSIP } \\
(3) ; \\
\text { UIP (1) }\end{array}$ & $\begin{array}{l}\text { Arthritis } \\
\text { (4); } \\
\operatorname{RP}(8)\end{array}$ & - & $\begin{array}{l}\text { anti-PmScl75 (4); anti-Pm- } \\
\text { Scl100 (1); anti-Ro52 (1); } \\
\text { anti-Ro60 (1); anti-RNAPIII } \\
\text { (1); anti-NOR90 (1); } \\
\text { anti-MDA5 (1); anti-Ku (1) }\end{array}$ \\
\hline $\begin{array}{l}\text { Necrotizing } \\
\text { myopathy (1) }\end{array}$ & $\begin{array}{l}\text { DAS } \\
\text { Skin } 0\end{array}$ & 80 & - & - & - & - \\
\hline
\end{tabular}

DM - dermatomyositis; CADM - clinically amyopathic dermatomyositis; MCTD - mixed connective tissue disease; PM - polymyositis; UCTD - undifferentiated connective tissue disease ILD - interstitial lung disease; NSIP - nonspecific interstitial pneumonia; LIP - lymphocytic interstitial pneumonitis; UIP - usual interstitial pneumonia; COP - cryptogenic organizing pneumonia; RP - Raynaud phenomenon
Objectives: To clinically characterize patients with inflammatory myopathies followed at an hospital's Rheumatology Department, using the Rheumatic Diseases Portuguese Register (Reuma.pt)

Methods: An observational transversal study was performed. Data on demographic variables, clinical features, antibodies and treatment were collected. Results: Of the 121 included patients, $78 \%$ were female, with a median age of 56 [44-68] years and a median disease duration of 2 [0-4] years. The mos frequent diagnosis was dermatomyositis ( $D M ; n=28,23 \%)$ followed by antisynthetase syndrome (ASyS; $n=21,17.4 \%$ ). At the time of the analysis, the median Manual Muscle Test (MMT-8) was 80 [78-80], the median modified skin Disease Activity Score was 0 [0-2] and global disease activity was 0.5 [0-0.75]. Calcinosis was found in $6 \%$ of the patients $(n=7)$, mostly DM cases. Interstitial lung disease (ILD) was present in 29 patients (24\%), of those, $52 \%(n=15)$ had antisynthetase syndrome (ASyS). Three patients presented as a paraneoplastic syndrome. Ninety-nine patients $(82 \%)$ had a myositis autoantibody identified: antisynthetase autoantibodies were the most commonly identified $(n=20,16 \%)$ $62 \%$ of the patients were treated with steroids and $35 \%$ with $\geq 2$ disease-modifying anti-rheumatic drugs.

Table 1 depicts the main clinical characteristics and the immunologic profile for each diagnosis

Conclusion: In our cohort the most frequent myositis subtype was DM. Almost a quarter of patients had associated ILD, which is an important cause of morbidity and mortality. ILD was more frequent in ASyS patients and was most commonly related to anti-Jo1 antibodies, which is consistent with the literature.

Disclosure of Interests: None declared.

DOI: 10.1136/annrheumdis-2021-eular.3150

AB0446
DEMOGRAPHIC AND CLINICAL FEATURES OF
IDIOPATHIC INFLAMMATORY MYOSITIS AND
PREVALENCE OF MYOSITIS-RELATED ANTIBODIES

G. K. Yardımcı ${ }^{1}$, E. Erul ${ }^{2}$, B. Farisoğulları ${ }^{1}$, G. Ayan ${ }^{1}$, L. Kılıç ${ }^{1}$, O. Karadag ${ }^{1}$, S. A. Bilgen '. ${ }^{1}$ Faculty of Medicine; Hacettepe University, Rheumatology, Ankara, Turkey; ${ }^{2}$ Faculty of Medicine; Hacettepe University, Internal Medicine, Ankara, Turkey

Background: Idiopathic inflammatory myopathies (IIM) are heterogeneous groups of connective tissue diseases. Diagnosis of IIM is sometimes challenging, but newly defined myositis specific autoantibodies (MSAs) are helpful in diagnosing of IIM and revealing the clinical signs [1].

Objectives: To describe demographic and clinical features of IIMs and to evaluate the frequency and clinical associations of myositis-specific and myositis associated antibodies (MAAs) in IIM.

Methods: Samples obtained from patients tested for MSA/MAA as of 2017 to 2020 were retrospectively evaluated. Patients were diagnosed with IIM according to clinician diagnosis. The prevalence and clinical associations of myositis-related antibodies were assessed with univariate and multivariate analysis.

Results: 152 patients (70.4\% female) were tested for myositis-related antibodies during the study period. 81 patients were diagnosed with IIM (38 DM, 43PM). DM patients were diagnosed at an earlier age and its association with malignancy was more relevant, although the relationship with malignancy was not statistically significant. Differences of clinical characteristics between DM and PM patients were skin features which were more frequent in DM, and interstitial lung disease which was more common in PM patients.

MSAs/MAAS were found in $65.4 \%$ and $43.2 \%$ in IIM patients, more frequently than patients without IIM ( $p=0.000$ and 0.0225 , respectively). MSAs were equally frequent in both IIM groups, whereas MAAs were more common in the PM group (although no significant difference in overlap with other connective tissue diseases within these two diseases). The most common MSAs in DM were antiTIF1- $\gamma(23 \%)$, anti-MDA5 (16\%), anti-NXP2 (13\%) and in PM were anti-Jo-1 (28\%), anti-MDA5 (12\%), anti-ku (12\%), anti-PL7 (12\%) respectively. Predictors of ILD in IIM were Anti-Jo-1 positivity and age (RR:10 [Cl:2-41] p=0.003 and RR:1.07 [Cl:1.02-1.12] $\mathrm{p}=0.04$ respectively)

Conclusion: The general characteristics of DM and PM patients and the frequencies of myositis-specific autoantibodies were similar to the literature, except that anti-TIF1- $\gamma$ antibodies (14\%) were more common in our Turkish cohort [2].

\section{REFERENCES:}

[1] Cruellas, M.G., et al., Myositis-specific and myositis-associated autoantibody profiles and their clinical associations in a large series of patients with polymyositis and dermatomyositis. Clinics (Sao Paulo), 2013. 68(7): p. 909-14.

[2] Gonzalez-Bello, Y., et al., Myositis-Specific Antibodies and Myositis-Associated Antibodies in Patients With Idiopathic Inflammatory Myopathies From the PANLAR Myositis Study Group. J Clin Rheumatol, 2020. 